\title{
IDENTIFICATION OF SOME ROOTSTOCKS FOR WATERMELON CULTURES FROM ROMANIA
}

\author{
Mădălina Doltu ${ }^{1 *}$, Elena Dragomir ${ }^{1}$, Bogdan Iordache $^{1}$, Dorin Sora ${ }^{1}$ \\ ${ }^{1}$ Institute of Research and Development for Industrialization and Marketing of Horticultural Products - Horting, \\ Drumul Gilăului, no. 5 N, District 4, 041715, Bucharest, Romania
}

Current Trends in

Natural Sciences

\begin{abstract}
Among the grafting aims are (1) to enhance plant growth, fruit yield and quality; (2) to control wilt caused by pathogens; (3) to reduce viral, fungal and bacterial infection; (4) to strengthen tolerance to thermal or saline stress; (5) to increase nutrient and mineral uptake to the shoot. The cultivars used to obtain of grafted seedlings were from the Baronesa F1 (Citrullus lanatus) hybrid scion and the Pelops F1 (Lagenaria siceraria), Kiwano (Cucumis metuliferus) and Zefir (Benicasa hispida) rootstocks. The rootstock has influenced the number of fruits per plant, weight/fruit and production/plant; the Pelops rootstock has had a positive influence and the Kiwano and Zefir rootstocks have had a negative influence compared to the non-grafted variant. The Pelops rootstock (105.84 t/ha) has had a positive influence and the Kiwano rootstock $(53.45 \mathrm{t} / \mathrm{ha})$ and Zefir rootstock $(51.38 \mathrm{t} / \mathrm{ha})$ have had have a negative influence compared to the non-grafted variant $(95.5 \mathrm{t} / \mathrm{h}$ a). The biometric measurements on watermelon fruit yield were made in 2020 year. The experience aimed the identification of some rootstocks for the watermelon cultures from Romania. The research shows that the rootstocks has influenced fruit yield and some grafting combinations researched may be recommended for cropping in Romania.
\end{abstract}

Keywords: Cucurbitaceae, grafted culture, rootstock, scion, yield.

\section{INTRODUCTION}

Among the grafting aims are (1) to enhance plant growth, fruit yield and quality (2) to control wilt caused by pathogens; (3) to reduce viral, fungal and bacterial infection; (4) to strengthen tolerance to thermal or saline stress; (5) to increase nutrient and mineral uptake to the shoot (Abd El-Wanis et al., 2013).

Specialists in grafting of cucurbits have researched some planting densities in the cultivation of grafted watermelons: 1980 - 3090 plants/ha (Milles et al., 2016), 3500 plants/ha (Bogoescu et al., 2011), 3600 plants/ha (Petropoulos et al., 2014), 4762 plante/ha (2000 plants/feddan) (Abd ElWanis et al., 2013), 5000 plants/ha (Torres et al., 2015).

In the researched watermelons, some researchers (Bogoescu et al., 2011; Kurum et al., 2017; Doltu et al., 2018) showed that the average fruit yield from the grafted watermelons is higher compared to non-grafted watermelons.

http://www.natsci.upit.ro

*Corresponding author, E-mail address: doltumadalina@yahoo.com 


\section{Current Trends in Natural Sciences}

Vol. 10, Issue 20, pp. 48-52, 2021

https://doi.org/10.47068/ctns.2021.v10i20.007

Current Trends in Natural Sciences (on-line)

ISSN: 2284-953X

Current Trends in Natural Sciences (CD-Rom)

ISSN: 2284-9521

ISSN-L: 2284-9521

ISSN-L: 2284-9521

Vegetable grafting has become a potential tool in stimulating the production in several countries. In recent years, grafting potential has been widely exploited to cope with abiotic stresses (Singh et al., 2017).

The objective of this research from the Horting Institute has been to identify and establish the influence of local and imported rootstocks on the productivity of some grafted watermelons.

\section{MATERIALS AND METHODS}

The watermelons are valuable vegetables, cultivated over all in world and with big share in Romanian crops.

The research was conducted at the Horting Institute - Bucharest, on a grafted and non-grafted watermelon collection cultivated in a greenhouse.

It was carried out during the years 2019-20, in the southeastern area of Romania, on a biological material consisting from a scion, Baronesa watermelon (Citrullus lanatus), three rootstocks, Pelops (Lagenaria siceraria), Kiwano (Cucumis metuliferus), Zefir (Benicasa hispida) and four work variants, V1- Bronesa, V2-Baronesa x Pelops, V3-Baronesa x Kiwano, V4-Baronesa x Zefir. The experiment with watermelons, grafted and non-grafted plants, has been set up in a Venlo glass greenhouse (figure 1) in the climate conditions from table 1.

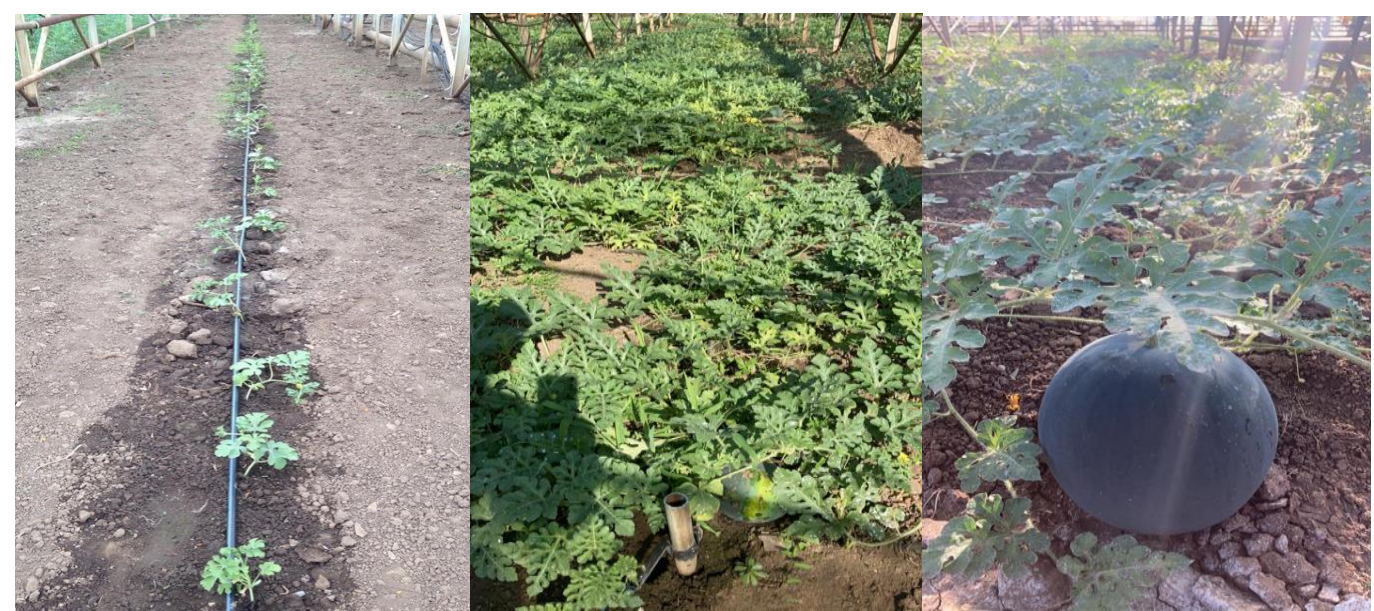

Figure 1. Experimental lot with Baronesa watermelons (different phenophases) at Horting Institute

Table 1. Climate conditions from greenhouses, Mai-August, 2020

\begin{tabular}{|c|c|c|c|c|c|c|c|c|}
\hline \multirow[t]{2}{*}{ Month } & \multicolumn{3}{|c|}{ Temperature $\left({ }^{\circ} \mathrm{C}\right)$} & \multicolumn{3}{|c|}{ Atmospheric humidity (\%) } & \multirow{2}{*}{$\begin{array}{c}\text { Soil } \\
\text { temperature } \\
\left({ }^{\circ} \mathrm{C}\right)\end{array}$} & \multirow{2}{*}{$\begin{array}{c}\text { Soil } \\
\text { humidity } \\
(\%)\end{array}$} \\
\hline & minimum & maximum & average & minimum & maximum & average & & \\
\hline May & 15.6 & 31.7 & 20.9 & 30.1 & 68.5 & 50.7 & 20.2 & 39.1 \\
\hline June & 14.9 & 39.2 & 25.5 & 28.1 & 86.3 & 61.3 & 21.4 & 30.8 \\
\hline July & 16.5 & 40.5 & 27.3 & 25.6 & 85.2 & 53.3 & 22.1 & 40.7 \\
\hline August & 16.2 & 40.1 & 27.4 & 22.5 & 81.8 & 49.4 & 25.1 & 50.6 \\
\hline
\end{tabular}

The experience was cultivated in a soil with some organic and chemical characteristics (table 2).

http://www.natsci.upit.ro

*Corresponding author, E-mail address: doltumadalina@yahoo.com 


\section{Current Trends in Natural Sciences}

Vol. 10, Issue 20, pp. 48-52, 2021

https://doi.org/10.47068/ctns.2021.v10i20.007

Table 2. Characteristics of soil

\begin{tabular}{|c|c|c|c|}
\hline Analyze & Result & MU* & Interpretation \\
\hline $\mathrm{pH}\left(20 \pm 2^{\circ} \mathrm{C}\right)$ & 8.04 & - & \\
\hline $\mathrm{EC}\left(25+1^{\circ} \mathrm{C}\right)$ & 0.475 & $\mathrm{mS} / \mathrm{cm}$ & \\
\hline \multicolumn{4}{|l|}{ CATIONS } \\
\hline $\mathrm{N}-\mathrm{NH}_{4}(\lambda=660 \mathrm{~nm})$ & 12.1 & $\mathrm{mg} / \mathrm{kg}$ & \\
\hline $\mathrm{K}(\lambda=766.490 \mathrm{~nm})$ & 32.9 & $\mathrm{mg} / \mathrm{kg}$ & \\
\hline $\mathrm{Na}(\lambda=589.592 \mathrm{~nm})$ & 117.3 & $\mathrm{mg} / \mathrm{kg}$ & \\
\hline $\mathrm{Ca}(\lambda=317.933 \mathrm{~nm})$ & 186.4 & $\mathrm{mg} / \mathrm{kg}$ & \\
\hline $\operatorname{Mg}(\lambda=279.077 \mathrm{~nm})$ & 65.1 & $\mathrm{mg} / \mathrm{kg}$ & \\
\hline \multicolumn{4}{|l|}{ ANIONS } \\
\hline $\mathrm{N}-\mathrm{NO}_{2}{ }^{-}+\mathrm{N}^{-\mathrm{NO}_{3}}{ }^{-}(\lambda=540 \mathrm{~nm})$ & 163.4 & $\mathrm{mg} / \mathrm{kg}$ & \\
\hline $\mathrm{Cl}^{-}(\lambda=470 \mathrm{~nm})$ & 123.1 & $\mathrm{mg} / \mathrm{kg}$ & \\
\hline $\mathrm{SO}_{4}^{2-}(\lambda=420 \mathrm{~nm})$ & 144.9 & $\mathrm{mg} / \mathrm{kg}$ & \\
\hline $\mathrm{P}(\lambda=213.617 \mathrm{~nm})$ & 218.0 & $\mathrm{mg} / \mathrm{kg}$ & \\
\hline \multicolumn{4}{|l|}{ MICROELEMENTS } \\
\hline $\mathrm{Fe}(\lambda=238.204 \mathrm{~nm})$ & 19.6 & $\mathrm{mg} / \mathrm{kg}$ & \\
\hline $\operatorname{Mn}(\lambda=257.610 \mathrm{~nm})$ & 8.2 & $\mathrm{mg} / \mathrm{kg}$ & \\
\hline $\mathrm{Zn}(\lambda=213.857 \mathrm{~nm})$ & 10.4 & $\mathrm{mg} / \mathrm{kg}$ & \\
\hline $\mathrm{B}(\lambda=249.677 \mathrm{~nm})$ & 0.3 & $\mathrm{mg} / \mathrm{kg}$ & \\
\hline $\mathrm{Cu}(\lambda=327.393 \mathrm{~nm})$ & 22.5 & $\mathrm{mg} / \mathrm{kg}$ & \\
\hline HUMUS & 2.48 & $\%$ & \\
\hline
\end{tabular}

The fertilization used in this research:

- Complex fertilizer ( $\left.\mathrm{N}_{16}-\mathrm{P}_{16}-\mathrm{K}_{16}, 300 \mathrm{~kg} / \mathrm{ha}\right)$ has been administered before planting,

- the $5^{\text {th }}$ days after planting - the $15^{\text {th }}$ day (/ha/day): ammonium nitrate $15 \mathrm{~kg}$ phosphate $9 \mathrm{~kg}$,

- the $16^{\text {th }}$ day $-30^{\text {th }}$ day (/ha/day): ammonium nitrate $12 \mathrm{~kg}$

- $\quad$ phosphate $3 \mathrm{~kg}$,

- the $31^{\text {st }}$ day $-45^{\text {th }}$ day (/ha/day): Polyfeed $\mathrm{N}_{20}-\mathrm{P}_{20}-\mathrm{K}_{20}+$ Microelements $6 \mathrm{~kg}$ ammonium nitrate $5 \mathrm{~kg}$,

- the $46^{\text {th }}$ day $-68^{\text {th }}$ day (/ha/day): ammonium nitrate $14 \mathrm{~kg}$,

- the $69^{\text {th }}$ day $-90^{\text {th }}$ day (/ha/day): Polyfeed $\mathrm{N}_{20}-\mathrm{P}_{20}-\mathrm{K}_{20}+$ Microelements $7 \mathrm{~kg}$,

- the $91^{\text {st }}$ day $-99^{\text {th }}$ day (/ha/day): ammonium nitrate $13 \mathrm{~kg}$.

Planting density was to 5000 non-grafted plants/ha and 3500 grafted plants/ha.

The biometric determinations were carried out on the watermelon fruits harvested from a research greenhouse at consumption maturity.

The statistical calculation was carried out by using the Duncan test $(\mathrm{p}=5 \%)$.

Planting density was to 5000 non-grafted plants/ha and 3500 grafted plants/ha.

The biometric determinations were carried out on the watermelon fruits harvested from a research greenhouse at consumption maturity.

The statistical calculation was carried out by using the Duncan test $(\mathrm{p}=5 \%)$. 


\section{RESULTS AND DISCUSSIONS}

In the grafted and non-grafted Baronesa watermelons, the influence of the rootstock on the fruiting at the culture from greenhouse is shown in tables 2 and 3; recorded results regarding the number of fruits/plant, the average weight/fruit and the production/plant are presented as medium values (average)/variant.

Table 2. Fruit yield on watermelon variants

\begin{tabular}{|c|l|r|r|r|}
\hline Variant & \multicolumn{1}{|c|}{$\begin{array}{c}\text { Combination } \\
\text { (scion x rootstock) }\end{array}$} & $\begin{array}{c}\text { Number of } \\
\text { fruits/plants }\end{array}$ & $\begin{array}{c}\text { Average } \\
\text { weight/fruit (kg) }\end{array}$ & $\begin{array}{c}\text { Production/plant } \\
(\mathrm{kg})\end{array}$ \\
\hline V1 & Baronesa & 3.2 & 5.97 & 19.1 \\
\hline V2 & Baronesa x Pelops & 4.2 & 7.20 & 30.24 \\
\hline V3 & Baronesa x Kiwano & 2.87 & 5.32 & 15.27 \\
\hline V4 & Baronesa x Zefir & 2.78 & 5.28 & 14.68 \\
\hline
\end{tabular}

The rootstock has influenced the number of fruits per plant, weight/fruit and production/plant; the Pelops rootstock has had a positive influence and the Kiwano and Zefir rootstocks have had a negative influence compared to the non-grafted variant.

Table 3. Watermelon yield per hectare (Duncan test, $p=5 \%$ )

\begin{tabular}{|c|l|r|r|}
\hline Variant & \multicolumn{1}{|c|}{$\begin{array}{c}\text { Combination } \\
\text { (scion x rootstock) }\end{array}$} & $\begin{array}{c}\text { Production } \\
(\mathrm{t} / \mathrm{ha})\end{array}$ & $\begin{array}{c}\text { Difference } \\
(\%)\end{array}$ \\
\hline V1 & Baronesa & $95.5^{\mathbf{b}}$ & 100 \\
\hline V2 & Baronesa x Pelops & $105.84^{\mathbf{a}}$ & +10.34 \\
\hline V3 & Baronesa x Kiwano & $53.45^{\mathbf{c}}$ & -42.05 \\
\hline V4 & Baronesa x Zefir & $51.38^{\mathbf{d}}$ & -44.12 \\
\hline
\end{tabular}

The Pelops rootstock (105.84 t/ha) has had a positive influence and the Kiwano rootstock (53.45 t/ha) and Zefir rootstock (51.38 t/ha) have had have a negative influence compared to the nongrafted variant $(95.5 \mathrm{t} / \mathrm{ha})$.

Kurum et al. (2017) showed that the average watermelon yield increased between $17.45 \%$ and $52.56 \%$ compared to the non-grafted system. Some researchers quoted by Doltu et al. (2018) showed that the grafting influenced the production: the highest unit production and mean weight were obtained with RS 841, which yielded $12013 \mathrm{~kg} / \mathrm{m}^{2}$ in combination x Pacio. With Paquito, RS 841 yielded $10623 \mathrm{~kg} / \mathrm{m}^{2}$ while the respective control value was $6855 \mathrm{~kg} / \mathrm{m}^{2}$ (Leoni et al., 1990); fruit yield was positively influenced by grafting (Ozlem et al., 2007); rootstock-scion combination affected plant growth and fruit yield (Petropoulos et al., 2004). Doltu et. al. (2018) showed that the the grafted watermelon had a superior production, production increase to $95 \%, 40.80 \mathrm{t} / \mathrm{ha}$ (Adam $\mathrm{x}$ Nimbus-NIZ 53-46) compared with 20.92 t/ha at ungrafted watermelon, control (Adam); 96\%, 36.75t/ha (Odem x Nimbus-NIZ 53-46) compared with $18.75 \mathrm{t} /$ ha at ungrafted watermelon, control (Odem); 98\%, 42.77 t/ha (Vasko x Nimbus-NIZ 53-46) compared with ungrafted watermelon, control (Vasko).

\section{CONCLUSIONS}

The rootstock has influenced fruit production per plant: the Pelops rootstock has produced higher production, more fruits per plant and more weight per fruit and the Kiwano and Zefir rootstocks have produced smaller fruits, less fruit per plant and less weight per fruit in all variants compared to the control variant. The research has showed that grafting on an appropriate rootstock (Pelops) has

http://www.natsci.upit.ro

*Corresponding author, E-mail address: doltumadalina@yahoo.com 


\section{Current Trends in Natural Sciences}

Vol. 10, Issue 20, pp. 48-52, 2021

https://doi.org/10.47068/ctns.2021.v10i20.007

positive effects on watermelon production per hectare compared to non-grafted watermelons and watermelons grafted on the other rootstock (Kiwano and Zefir). The research on other rootstocks, but also other variants of planting density per hectare and fertilization programs are recommended for the grafted watermelons.

\section{ACKNOWLEDGEMENTS}

This research was financed by the Ministry of Agriculture and Rural Development (MADR) from Romania (Agricultural Research and Development Program 2019-2022, ADER 7.3.1 project).

\section{REFERENCES}

Abd El-Wanis, M., El-Eslamboly. A.A.S.A., Salama, M. A. (2013). Impact of Different Grafting Methods on Yield and Quality of Watermelon. Research Journal of Agriculture and Biological Sciences, 9(6), 330-340.

Bogoescu, M., Sora, D., Mohora, A., Doltu, M. (2011). Tehnologia de cultură în câmp a pepenilor verzi altoiţi. Oferta Cercetării Ştiinţifice pentru transfer tehnologic în agricultură, industria alimentară şi silvicultură, XIV, 117118.

Doltu, M., Sora, Dorin, Șovărel, G. (2018). Results on a grafted watermelon organic culture from Bucharest for pollution reduction and efficient use of land destined to urban research and education. Urban Planning, Architecture and Design, Section Urban Studies, 5(2), 167-174.

Kurum, R., Çelik, I., Eren, A. (2017). Effects of rootstocks on fruit yield and some quality traits of watermelon (Citrullus lanatus). Makale Bilgisi/Article InfoDerim, 34(2), 91-98.

Leoni, S., Grudina, R., Cadinu, M., Madeddu, B., Carletti, M.G. (1990). The influence of four rootstocks on some melón hybrids and a cultivar in greenhouse. Acta Horticulture, 287, 127-134.

Milles, C., Kubota, C., Zhao, X. (2016). Vegetable Grafting International Field. Trip Report - Part II, Sicily, Italy.

Ozlem, A., Nilay, O., Yasemin, G. (2007). Effect of Grafting Watermelon Plant Growth, Yield and Quality. Asian Network for Scientific Information, Journal of Agronomy, 6(2), 362-365.

Petropoulos, S.A., Olympios, C., Ropokis, A., Vlachou, G., Ntatsi, G., Paraskevopoulos, A., Passam H.C. (2014). Fruit Volatiles, Quality, and Yield of Watermelon as Affected by Grafting. J. Agr. Sci. Tech., 16, 873-885.

Petropoulos, S.A., Olympios, C., Ropokis, A., Vlachou, G., Ntatsi, G., Paraskevopoulos. A., Passam. H.C. (2004). Fruit Volatiles, Quality, and Yield of Watermelon as Affected by Grafting. Journal of Agricultural Science and Technology, 6, 873-885.

Torres, M., Herouard, C., Fournier, C. (2015). Grafting in France. 